\section{Conversa com Aldyr Schlee (parte I): futebol local e narrativas de fronteiras}

\author{
Conversation with Aldyr Schlee (part I): \\ local football and border narratives
}

\section{Gustavo Cerqueira Guimarães}

Universidade Federal de Minas Gerais (UFMG), Belo Horizonte / Brasil Doutor em Teoria da Literatura e Literatura Comparada, UFMG

gustavocguimaraes@hotmail.com

\section{Aldyr Garcia Schlee}

Universidade Federal de Pelotas (UFPel), Pelotas / Brasil

Doutor em Ciências Humanas, UFRGS

\section{Giulia Piazzi}

Centro Federal de Ed. Tecnológica (CEFET-MG), Belo Horizonte / Brasil

Mestranda em Estudos de Linguagens, CEFET-MG
Resumo: Conversa com o escritor, desenhista, criador da camisa Canarinho, jornalista e professor gaúcho Aldyr Schlee, realizada por Gustavo Cerqueira e editada por ele, em parceria com Giulia Piazzi. No diálogo do escritor com a revista FuLiA / UFMG, bem como em sua obra ficcional, o futebol é colocado diretamente em contato com questões relativas ao local e às fronteiras (Jaguarão/Brasil e Río Branco/Uruguai) e com os desvios e desencaixes identitários evocados por meio de flashes autobiográficos tanto do entrevistado quanto do entrevistador (Lajinha/MG e Ibatiba/ES).

PalaVRas-CHAVE: Aldyr Schlee; Futebol e memória; Narrativas de fronteira; Copa A Gazetinha de Futebol Infantojuvenil; Autoedição.

ABSTRACT: Conversation the with writer, designer, creator of Canarinho shirt, journalist and professor Aldyr Schlee, made by Gustavo Cerqueira and edited by him, in partnership with Giulia Piazzi. In the writer's dialogue with the FuLiA / UFMG magazine, as well as in his fictional work, football is put directly in contact with questions related to the place, the border (Jaguarão/Brasil and Río Branco/Uruguai and Lajinha/MG and Ibatiba/ES) and the deviations and dislocations of identity, evoked by autobiographical flashes by both of the interviewee and of the interviewer.

KEYWORDS: Aldyr Schlee; Football and memory; Border narratives; Copa A Gazetinha de Futebol Infantojuvenil; Self-editing. 


\section{Preliminares}

À tarde era futebol. Sempre havia futebol no campo do Harmonia ou no do Cruzeiro, às vezes em Río Branco. Eram dias de solaços, de calorões, e de luminosidades de se apertar as vistas; dias de se suar na sombra, de se jogar no corpo do adversário com raiva, de se buscar o golo de qualquer jeito, de ter prazer na sede e no cansaço, de se ter orgulho da goela seca e do roxão na perna. Saía de casa logo depois do almoço e ia passando pelas casas dos amigos, em direção ao campo. Chegavam alegres, tiravam a roupa às risadas, botavam o fardamento usado do $2^{\circ}$ quadro e iam para a cancha como se fossem jogar pela primeira vez.

Contos de futebol, Aldyr Schlee.

Aldyr Garcia Schlee - Chilê, pronúncia aportuguesada - é escritor, jornalista, tradutor, livre-docente, aposentado pela Universidade Federal de Pelotas/RS, e desenhista. Nasceu no dia 22 de novembro de 1934, em Jaguarão/RS, uma pequena cidade ao extremo sul do Brasil, na divisa com Río Branco, Uruguai, onde sua literatura é bastante conhecida pela abordagem de temáticas fronteiriças.

No âmbito estritamente futebolístico, destacam-se dois trabalhos desse extraordinário artista gaúcho: Contos de futebol (1997), que é um dos principais livros "nacionais" a tratar sobre esse esporte como elemento central de sua narrativa, lançado primeiramente no Uruguai, em 1995; e o desenho do uniforme da seleção brasileira de futebol, criado por ele em 1953, aos 19 anos, para o concurso que elegeria os novos trajes para disputa da Copa do Mundo de 1954, na Suíça.

No Mundial anterior, o escrete havia sofrido sua mais trágica derrota esportiva, em casa, para o Uruguai, conhecida como Maracanazo. Na ocasião, a seleção vestia um uniforme predominantemente branco com detalhes em azul, que não expressava a vibração do país, segundo o edital do concurso. Para mudar isso, o periódico carioca Correio da Manhã promoveu, com o aval da Confederação Brasileira de Desportos, o concurso de desenhos, solicitando que fossem utilizadas as quatro cores da nossa bandeira. Desde então, a Canarinho, de Aldyr Schlee, tornouse um símbolo fortíssimo da identidade brasileira.

O contista gaúcho estreou na literatura com Contos de sempre (1983) e, dentre muitos outros livros de destaque, 
publicou O dia em que o Papa foi a Melo (1999), adaptado para o cinema com o título El baño del Papa (2007), e Os limites do impossível: contos gardelianos (2009), que narra histórias interligando dramas de mulheres de distintas nacionalidades, raças, idades e classes sociais. ${ }^{1}$

Schlee "inventou, delimitou e transita em seu próprio mundo literário", que vem ganhando cada vez mais a atenção dos leitores e da crítica especializada. Isso muito se deve, apontando para apenas um traço de seus textos, aos espaços transitados pelos seus personagens, oriundos daquelas cidades e regiões limítrofes do pampa, mas experienciadas por eles "sem as fronteiras da diferença, consolidadas de forma imaginária no limiar da igualdade". ${ }^{2}$

${ }^{1}$ Outras obras de Schlee: Uma terra só (1984), Linha divisória (1998), Contos de verdades (2000), Contos gauchescos e lendas do Sul (2007), Glossário de Simões Lopes Neto (2009), Don Frutos (2010), Contos da vida difícil (2013), Memórias de o que já não será (2014) e Fitas de cinema (2015). Atualmente, Schlee está em vias de publicar um dicionário da cultura pampeana, resultado de um trabalho de pesquisa elaborado com base em autores brasileiros, argentinos e uruguaios, contendo informações sobre tipos de animais, vegetações e plantas medicinais.

Para um maior aprofundamento no assunto, conferir os artigos "Invenção literária e imaginário fílmico em 'O barco das ilusões'”, de João Manuel dos Santos Cunha, Nonada, PUC-Minas, v. 2, n. 13, 2009, p.
Como exemplo, segue um fragmento do desfecho final do conto "Aquela tarde impossível", no qual o guri, que morava em Jaguarão, de dentro do cinema em Río Branco, no Uruguai, surpreende-se enredado em inusitadas emoções ao saber que o Brasil tinha acabado de perder a Copa do Mundo de 1950 para nuestros hermanos.

Subitamente é interrompida a projeção do Cine Río Branco e se acendem as luzes, [...] uma voz grave anuncia que, no Rio de Janeiro, o Uruguai acaba de ganhar do Brasil: 2 × 1 .

Los uruguayos eran los campeones del mundo!

[...] Os guris não esperam o filme terminar. Saem sem palavras e vão embora devagar, as mãos nos bolsos das campeiras, chutando as pedras entre os dormentes da Ponte.

Los uruguayos eran los campeones del mundo!

Eu estaria chorando sem saber por quê. Chorando de emoção, é claro; mas de uma emoção pura, que não era de alegria nem tristeza, nem era de certeza nem de dúvida. $^{3}$

113-123, 2009; "Literatura e futebol no espaço fronteiriço: a construção de uma identidade provisória no conto 'Empate', de Aldyr Garcia Schlee", de João Luis Ourique e Alexandre Antonio Maciel, publicado na revista Aletria, UFMG, v. 26, n. 3, p. 49-68, 2017.

${ }^{3}$ SCHLEE. Contos de futebol, p. 30-31. 


\section{REGRAS DO JOGO}

Encontrei-me com o Schlee em sua casa, em Pelotas, no dia 15 de maio de 2017, segunda-feira, às $10 \mathrm{~h}$ de uma manhã bastante fria, depois de trocarmos algumas mensagens por e-mail intermediadas pelo Luiz Heron da Silva e pelo Alfredo Aquino, seu editor, a quem agradecemos.

Antes de iniciar a gravação de grande parte de nossa conversa, fizemos um preâmbulo de uns vinte minutos a fim de estabelecer os rumos que a entrevista iria tomar. Logo, percebemos que estávamos bem à vontade um com o outro. Afinal de contas, falar sobre futebol aproximam as pessoas, não é mesmo?

Assim, o que seria uma entrevista passou a se configurar como uma conversa, uma prosa que, a seu convite, estendeu-se até o Mercado Central de Pelotas para o almoço, onde pude perceber ainda mais o quanto o Aldyr é uma pessoa elegante, simples e de uma erudição admirável, atributos que igualmente se aplicam à sua literatura.
Apesar do papo fluido, com pouco mais de duas horas capturadas, e posteriormente transcritas com fidelidade implacável, os três principais assuntos motivadores do encontro foram contemplados: o livro Contos de futebol, a criação do uniforme da seleção brasileira - ambos em fases distintas de edição,$-{ }^{4}$ e a relação de Schlee com o futebol nos anos 1940 e 1950, na cidade fronteiriça de Jaguarão.

A entrevista que se segue é, portanto, parte de uma agradável conversa entre Aldyr e Gustavo e reflete as influências que as fronteiras e o futebol podem exercer sobre os sujeitos, traçando diversas peculiaridades, pois, de carona, são igualmente suscitadas as memórias fronteiriças e futebolísticas de infância, nos anos 1980, do entrevistador, em Lajinha/MG e em Ibatiba/ES, cidade pela qual disputou a competição de futebol infantojuvenil mais tradicional do país, a Copa A Gazetinha, criada na capital capixaba, em $1976,{ }^{5}$ pelo visionário jornalista José Antô-

\footnotetext{
${ }^{4}$ A publicar com os seguintes títulos: "Conversa com Aldyr Schlee (parte II): Contos de futebol" e "Conversa com Aldyr Schlee (parte III): a camisa da seleção brasileira".

5 "A Copa A Gazetinha de Futebol Infantojuvenil" foi fundada em 1976, em Vitória/ES, com promoção do jornal A Gazeta. Hoje, A Gazetinha é
} 
nio Nunes do Couto, o JANC, que, curiosamente, também nasceu na fronteira desses estados, em Aimorés/MG, divisa com Baixo Guandu/ES, em 1935.

Do ponto de vista formal, uma de nossas preocupações foi a de manter o caráter oral da entrevista, sua performatividade, sem, contudo, perder o rigor da escrita. Para tanto, foi preciso cortar trechos repetitivos, ligar as frases com conectivos mais precisos e acrescentar algumas referências, datas e notas.

\section{O JOGO}

Gustavo Cerqueira Guimarães: Inicialmente, vou pedir sua licença pra me apresentar melhor e falar um pouco sobre as principais motivações de vir aqui te encontrar. Uma delas foi por ter lido, em 2014, o seu livro Contos de futebol (1997) e trabalhado com três dos contos em minhas disciplinas de lite-

disputada por equipes dos municípios do Espírito Santo (e convidados de outros estados), nas categorias sub-11, 12/13 e 14/15 anos. ratura na Faculdade de Letras da UFMG - "Aquela tarde impossível”, "Empate" e "A falta de Tabaré”. ${ }^{6}$

O seu livro fez com que eu me lembrasse muito de minhas próprias histórias relacionadas com o futebol, pois ele fala do futebol de sua infância nos anos 1950, em Jaguarão/RS, na fronteira com Río Branco, no Uruguai. Portanto, eu gostaria de conversar com você sobre as minhas e as suas histórias futebolísticas, e também sobre as "nossas fronteiras".

Aldyr Garcia Schlee: Sim, sim, podemos falar sobre isso, teremos tempo...

Gustavo: Ótimo. Muito obrigado! Fico realmente muito feliz e lisonjeado, pois o dossiê da revista FuLiA / UFMG, onde pretendemos publicar parte desta conversa, propõe pensar o futebol em seu contexto mais local, na tentativa de fugir um pouco das narrativas canônicas do Rio de Janeiro e de São Paulo. Afinal, o futebol, desde o início, esteve em todo lugar, né?

\footnotetext{
${ }^{6}$ Livro publicado no Uruguai, em Montevidéu, pela Ediciones de la Banda Oriental, em 1995, com o título Cuentos de fútbol, traduzido ao espanhol por I. Ariel Villa, Heber Raviolo, Pablo Rocca. Dois anos depois, foi publicado em português, em Porto Alegre, pela editora Mercado Aberto.
} 
Aldyr: Claro, claro, do sul ao norte do país.

Gustavo: Pois é. Recentemente, por exemplo, um pesquisador da UFMG publicou um artigo sobre o que talvez seja o primeiro romance brasileiro sobre futebol, que se chama $O$ grande desportista, de 1922, de um escritor de Uberaba/MG, o Pascoal Toti Filho. ${ }^{7} 0$ pesquisador, Cleber Dias, encontrou esse livro por acaso na Biblioteca Nacional. Assim, o romance Flô, o goleiro melhor do mundo (1941), de Thomaz Mazzoni (19001970), perdeu o status de primeiro romance sobre futebol publicado no Brasil, como tanto a imprensa e os estudos sobre futebol andaram divulgando.

Hoje, com as revistas eletrônicas acadêmicas, está muito mais fácil divulgar nossas pesquisas, e a tendência é que a gente tenha mais cuidado pra falar sobre pioneirismos editoriais no futebol, temos que ter mais cautela pra afirmar que determinada obra é a primeira (risos), porque, vira e mexe, a gente descobre pesquisas como essa que nos revelam um livro esquecido, publicado

\footnotetext{
${ }^{7}$ TOTI FILHO, Pascoal. O grande desportista. Uberaba: Typographia A Século XX, 1922. Conferir o artigo "Literatura, esportes e regionalismo no Brasil: O grande desportista, de Pascoal Toti Filho", publicado pela Aletria, v. 26, n. 3, p. 69-86, 2017, de Cleber Dias.
}

em Uberaba, no interior de Minas, ainda no primeiro quarto do século passado.

Aldyr: Ah, disso eu não tinha ideia... Eu não sabia.

Gustavo: É incrível, né? Não li $O$ grande desportista. Eu só li esse artigo sobre ele, que fala sobre a presença da mulher nos jogos da cidade e o futebol jogado em Uberaba e em São Paulo. Ou seja, as relações entre futebol, gênero e geopolítica interior e capital - já eram temas relevantes.

Também tenho interesse nesses temas, porque, como já te disse por e-mail, sou pesquisador do FULIA, um núcleo de estudos sobre Futebol, Linguagem e Artes, fundado em 2010 pelos pesquisadores Elcio Cornelsen e Marcelino da Silva. 0 Elcio é paulistano, fez sua formação em germanística na USP e vive em Belo Horizonte desde 2001, quando entrou pra Faculdade de Letras da UFMG. O Marcelino é belo-horizontino mesmo, é professor de Teoria da Literatura. Talvez ele seja o primeiro, senão o único, pesquisador brasileiro a ter feito mestrado e doutorado sobre literatura e futebol no âmbito dos Estudos Literários. 0 mestrado dele foi sobre Nelson Ro- 
drigues, na década de 1990, quando era um tema marginal na área de Letras. No doutorado, pesquisou a obra do irmão do Nelson, o Mário Filho.

Aldyr: Que beleza! O Mário Filho... É o chute inicial, né, o pontapé inicial. Precisamos mesmo cada vez mais produzir trabalhos à altura do futebol que nós praticamos.

Gustavo: Isso! O Marcelino tem um livro importante pros estudos futebolísticos, o Mil e uma noites de futebol: o Brasil moderno de Mário Filho (2006), que saiu pela editora da UFMG. Já, o Elcio publicou dezenas de artigos sobre futebol no Brasil e no exterior e coorganizou alguns livros e dossiês de periódicos, como o "Esporte na literatura e no cinema", pela Aletria, na qual saiu o artigo sobre $O$ grande desportista.

Agora, com o nosso núcleo mais consolidado, fundamos a revista FULiA / UFMG, com o objetivo principal de publicar artigos e ensaios, além de textos literários, sonoros e audiovisuais na seção Poética.

Na seção Entrevista, pretendemos registrar depoimentos de figuras que se relacionaram com o futebol ou o estetizaram de modo especial, como você, pois, sem dúvida, o Contos de futebol é um dos dois livros mais importantes do gênero publicado no Brasil. O outro, claro, até pelo ineditismo da iniciativa, é Maracanã, adeus: onze histórias de futebol (1980), do Edilberto Coutinho (1933-1995).

Aldyr: Vencedor do Prêmio Casa de Las Americas... Tive a felicidade de conhecê-lo.

Gustavo: Sim, o livro do Edilberto é incrível, né, cheio de temas sociais que repercutem até hoje em nossa sociedade: o papel da mulher, o negro no futebol e os personagens do povo, subalternos e desajustados. Mas, quando li o seu livro, a identificação foi ainda maior, pois ele fala de um futebol no passado, ele fala de memória... E toca numa questão bastante peculiar, a vivência fronteiriça dos personagens. Eu também nasci numa fronteira, mas não numa fronteira internacional como a que você e os seus personagens nasceram (risos). Eu nasci numa fronteira interestadual, na divisa de Minas Gerais com o Espírito Santo. Eu nasci em Lajinha/MG, divisa com Ibatiba/ES, cidades que pertencem à região interestadual do 
Caparaó, uma região cafeicultora, onde fica o Pico da Bandeira. Lá, tinha um pouco disso que tem em seu livro, aquele lance de ter uma diferença (e semelhança) com o vizinho da fronteira, com o outro...

Aldyr: Sim, claro, uma fronteira histórica essa! Muitas batalhas. Nessa região, Espírito Santo e Minas Gerais são muito parecidos, não é?

Gustavo: Exatamente! É uma região conhecida também por conta da "Guerrilha do Caparaó", na época da ditadura (196667), e pelo conflito que se arrastou ao longo de quase todo o século passado, a "Guerra do Contestado". Em alguns períodos, aquela região era "neutra", porque não se sabia ao certo os limites entre os estados, entre as cidades, sei lá... Não sei bem direito essa história.

Só sei que um dia, costumo brincar, fizeram um risco no mapa e inventaram a divisa, criaram Lajinha e Ibatiba (risos). Uma reta imensa constitui a delimitação das cidades, são aproximadamente 36 km, eu cheguei a medir pelo Google Earth.

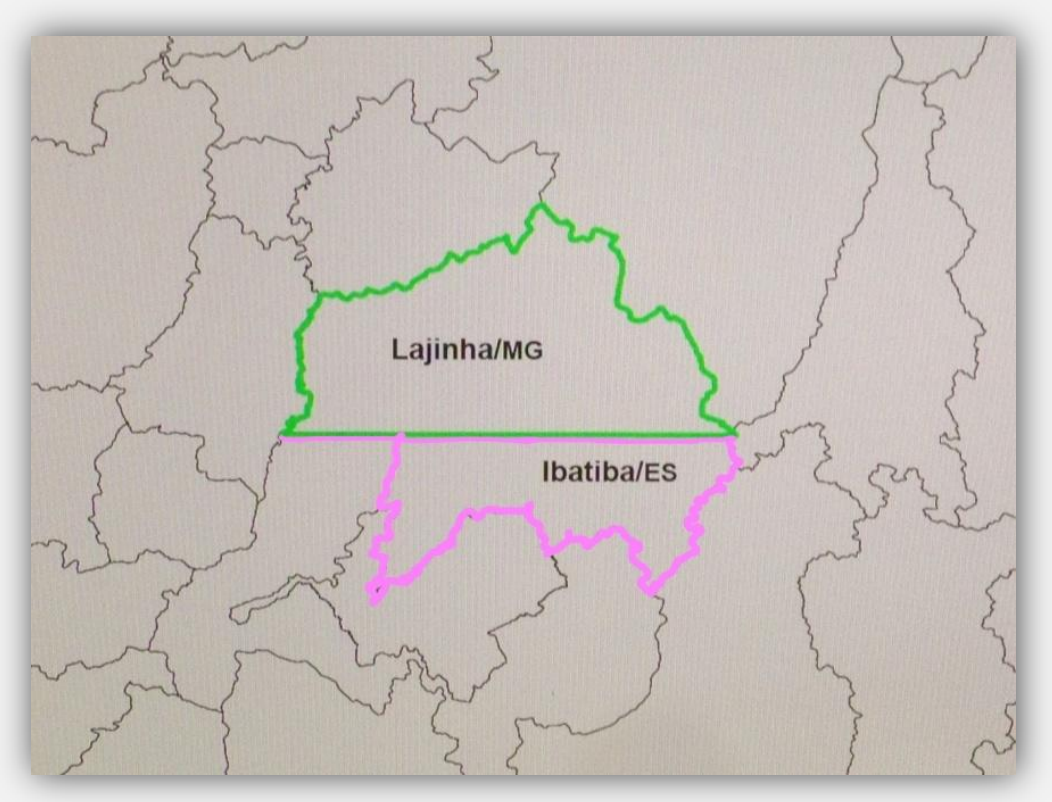

Mapa de Lajinha/MG e Ibatiba/ES.

Clique no link para expandir o mapa: https://goo.gl/1vygGX.

Desde pequeno, me lembro bem, essa reta louca no mapa me intrigava nas aulas de Geografia. Afinal, não tinha um rio e nem uma montanha pra separar as cidades, como é comum entre as outras divisas. Então, passaram uma régua, fizeram uma linha reta, foram no cartório e pronto! De repente, cria- 
ram Lajinha e Ibatiba (risos). Uma linha reta é sempre uma imposição, né? Não existe correspondente na natureza.

Meu pai [Enock] e minha mãe [Alzira], que também são lajinhenses, separaram-se em 1980, quando eu tinha uns seis anos. Em 1982, meu pai se casou novamente e, em 1986, mudou-se pra Ibatiba, terra de sua mulher, a Dora. Ele morou por lá nos seus últimos 30 anos de vida, tinha um escritório de advocacia, era criminalista. Meu pai morreu de câncer no ano passado [2016], aos 78 anos, por isso ando pensando muito nos tempos antigos, sobretudo os relacionados a ele.

O papai era um pouco mais novo do que você, ele nasceu em 1938, ano da emancipação de Lajinha. Mas ele acabou se mudando pra Ibatiba - atravessando a fronteira - por volta de seus 50 anos. Apenas $20 \mathrm{~km}$ separam os dois centros das cidades. Quando eu era pequeno, eu ia direto pra casa dele, de ônibus, sozinho. Adorava ir pra Ibatiba, embora muitos colegas e pessoas de Lajinha ficassem me falando mal de lá, como coisas do tipo: "Ibatiba não é lugar de ir, é lugar de voltar", "Ibatiba não é cidade, é uma BR" (risos) - falavam por causa da BR-262, inaugurada em 1969, que passa no meio da cidade. ${ }^{8}$ Isso, inclusive, ajudou e muito a levar certo desenvolvimento pra Ibatiba. Em 2010, instalaram um excelente Instituto Federal de Educação (IFES), justamente às margens dessa BR.

Naquela época, tinha uma piadinha péssima que dizia que "o capixaba, na verdade, é um baiano, metido a carioca, com inveja do mineiro". Era comum de se ouvir na rua que o pessoal de lá era "da roça", que eles eram macaqueiros, ignorantes, violentos. Enfim, que eles eram capixabas. Uma rixa histórica, viu... Talvez muito dessa fama, não sei ao certo, tenha vindo por conta de um linchamento que houve na cidade, no início dos anos 1980, quando "a população" matou com as próprias

\footnotetext{
${ }^{8}$ Informações históricas sobre a BR-262: "Nos últimos anos da década de 1940, divulgou-se que uma nova rodovia federal seria construída e cortaria a região, passando por lbatiba, mas somente na década de 1950 foram feitas as primeiras demarcações da nova rodovia. Mais tarde, em 1963, foram iniciadas as obras de construção [...]. Com a inauguração da BR-262, em 1969, o Distrito de lbatiba passou a ter mais acesso à comercialização de produtos variados e a receber maior número de imigrantes. Tal fato fez com que o distrito se desenvolvesse rapidamente em poucos anos, o que despertou o desejo de emancipação política e administrativa de seus moradores. Para tanto, na década de 1970, foi criada a ADI (Associação Pró-Desenvolvimento de Ibatiba) por iniciativa de representantes da liderança local" - Site da Câmara Municipal de Ibatiba: https://goo.gl/AVDZAt.
} 
mãos cinco caras que assaltaram um banco de lá. Foi notícia nacional. ${ }^{9}$

\section{Aldyr: Terrível!}

Gustavo: Pois é, uma coisa complicada, mas que não justifica a postura arrogante e preconceituosa do pessoal de Lajinha, postura muito discriminatória. Poxa, eu ia pra Ibatiba e não sentia nada disso, sabe? Lá era diferente, claro, mas não era ruim, era bom.

Lajinha é muito mais perto de Vitória/ES (a $180 \mathrm{~km}$ ) do que de Belo Horizonte/MG (a 350 km). 0 Estado de Minas só chegava lá na hora do almoço (risos). Pela manhã, a gente lia um jornal capixaba, A Gazeta, de Vitória. A gente lia as notícias sobre os times cariocas. Até hoje, os torcedores de lá são predominantemente dos times do Rio. Eu sempre torci pro Atlético Mineiro, minha família era uma raríssima exceção.

\footnotetext{
${ }^{9}$ Em 1983, "o Espírito Santo foi destaque na mídia nacional como o Estado em que a população, desacreditada nas instituições e revoltada com a morte de um policial militar, retirou cinco assaltantes de banco de dentro de uma viatura e os matou em praça pública, na porta da Delegacia de Ibatiba". Mais detalhes no "Blog do Elimar Cortês" https://goo.gl/TYGnE4.
}

E pra falar um pouco mais dessa experiência de fronteira, há uma história bem marcante pra mim, que foi em janeiro de 1999, quando eu viajei pra Europa pela primeira vez, aos 24 anos. Eu estava me formando em Psicologia. Numa viagem de trem, de San Sebastián (Espanha) pra Roma, conheci um jovem seminarista de uma maneira muito especial. Ele embarcou no trem em que eu estava, ao passar na cidade de Lourdes, na França. Quando ele subiu, eu estava morrendo de fome (risos), pois eu não tinha dinheiro algum pra comprar comida, o meu cartão de crédito tinha dado um tilt na cidade basca. Tentei usá-lo em três lugares e não funcionava. Paguei a hospedagem com todo o dinheiro que eu tinha e pensei que só comeria alguma coisa na Itália, onde encontraria um amigo de Belo Horizonte.

Nesse contexto, quando o cara me perguntou se aquele trem iria mesmo pra Roma, foi que eu saquei o jeito dele parecido com o meu, o sotaque, talvez, e logo perguntei se ele era brasileiro. Pra minha grata surpresa, ele era de Cachoeiro de Itapemirim/ES, cidade que eu conhecia por ter jogado as finais da Copa A Gazetinha, em 1988. E, claro, também era a terra do Roberto Carlos. A gente estava sozinho na cabine, e me lembro 
de cantar "Cavalgada" por diversas vezes durante a viagem, música que tanto ouvi com a minha mãe na infância, além de outras, pois tínhamos discos e fitas cassetes do Rei em casa. Em Lajinha tinha um programa de rádio local que só tocava Roberto, o "Almoçando com o Rei", que começava às $11 \mathrm{~h} 30$, depois do colégio.

Naquele dia, eu percebi o quanto eu era capixaba, o quanto o Espírito Santo compunha minha identidade, sabe? Foi uma experiência identitária, uma sintonia muito bacana entre a gente. Afinal, ele tinha um pacote cheio de sanduíches e galões d'água da fonte sagrada de Lourdes (risos). E o cartão até voltou a funcionar logo quando cheguei à estação, em Roma (risos).

Aldyr: Um verdadeiro milagre (risos).

Gustavo: E o mais curioso ainda foi que, ao voltar pro Brasil, o seminarista "estagiou" numa igreja católica exatamente em Ibatiba, onde deu aulas de violão pro meu irmão por parte de pai, o mais velho, o Raphael. Quando fui a Ibatiba, meu pai fez questão de convidar o "padre" pra almoçar lá em casa pra lhe dar um presente - um agradecimento.
Enfim, eu só queria mesmo compartilhar algumas lembranças ligadas ao meu espaço de fronteira e ao futebol, porque o seu livro me fez refletir sobre elas, pois joguei três anos pelo time infantojuvenil de Ibatiba, disputando a Gazetinha, em 1987, 1988 e 1989. Agora, estou tentando organizar essas memórias. Talvez, no futuro, eu as reinvente como você fez com as suas. Portanto, gostaria também de registrá-las... Posso continuar?

Aldyr: Claro, claro, também lhe contarei as minhas...

Gustavo: Eu comecei a jogar bola já na 1a série, em 1981, no pátio e na quadra da escola estadual em que eu estudava. Eu jogo até hoje e ando mal das pernas (risos). Mas foi em 1987, aos 12 anos, que eu comecei a jogar bola mesmo, muito a sério, treinando sistematicamente num campo oficial pra disputar a Copa A Gazetinha pelo time de Ibatiba.

Apesar de eu ter muito mais prazer de jogar na linha do que no gol, o destino fez de mim, naquela época, um goleiro. $\mathrm{Na}$ verdade, eu era bem melhor no ataque, corria muito, mas tinha boa colocação debaixo do gol e, como sempre faltava gente pra jogar na posição, eu acabava por lá também. Meus primeiros 
ídolos que jogavam no gol foram o Zoff, goleiro da Itália na Copa de 1982, e o Carlos e o Taffarel da seleção brasileira.

Um dia, o pai do Rodrigo, um parceirão de infindas peladas, chamou o técnico do time de Iúna/ES pra mostrar o futebol da meninada no campinho da casa dele. Me lembro que foi numa noite - lá, tinham refletores - e que eu me revezei na linha e no gol. No final, ele escolheu cinco jogadores pra treinar em Iúna e tentar a chance de disputar a Gazetinha pelo hoje centenário clube Rio Pardo, o "Gigante do Caparaó”. Os escolhidos foram: Guto, Lander, Marquinho "Bicudo", Rodrigo e Roger. Eu fiquei de fora, mas o técnico Romildo me falou que o time de Ibatiba estava precisando de um goleiro, que era pra eu procurar o Romário Nóia, o técnico, pra fazer um treino. Feito isso, acabei disputando três edições da Copa: 1987 (categoria 12/13 anos), 1988 e 1989 (14/15 anos). O nosso time foi vice-campeão nos dois primeiros anos e viajamos muito, a convite, por dezenas de cidades do Espírito Santo pra disputar amistosos, geralmente, aos domingos de manhã.
Em 1987, fui titular nas duas primeiras fases da Copa e reserva nas finais. Na segunda fase, disputada em Castelo/ES, jogamos contra o tradicional Ordem e Progresso, ${ }^{10}$ time de Bom Jesus do Norte, que, apesar desse nome, fica ao sul do Espírito Santo, na fronteira com Bom Jesus do Itabapoana, Rio de Janeiro. Eles tinham um sotaque carioca (risos).

Esse jogo foi debaixo de um temporal, o gramado estava pesado, bastante barro e poças, mas nosso time entrou muito concentrado e ganhou de 1 a 0 . Me lembro também que o Quim, talvez o melhor jogador daquele time, tirou uma bola praticamente de dentro do gol, e me lembro que eu defendi um pênalti no segundo tempo, o empate favorecia ao Progresso, e a gente se classificou pra fase final. Esse foi o meu momento de glória no futebol (risos).

Na Gazetinha de 1987, o Quim era minha referência dentro de campo. Ele era muito vibrante e me contagiava. Ele era im-

\footnotetext{
${ }^{10} \mathrm{O}$ time era comandado pelo Tim-Tim, Fausto Gomes da Silveira, um dos mais tradicionais técnicos da Gazetinha, que atuou pelo clube de 1985 a 2009. Foi campeão ao derrotar a Desportiva Ferroviária, em 1986, e foi o treinador da seleção da Gazetinha que participou de um torneio nos EUA, em 1988.
} 
pressionante, porque treinava e jogava com o mesmo entusiasmo. Nós jogamos juntos durante três anos, chegando e saindo dos treinos lado a lado, pois pegávamos o mesmo ônibus. Ele morava em Santa Clara/ES, um povoado mais perto de Lajinha. Ele tinha o cabelo grande, tipo o daqueles jogadores argentinos dos anos 1980, era da minha altura, mas bem mais forte, chutava com muita força. Era voluntarioso, combativo e polivalente. Eu já vi o Quim jogar em várias posições numa mesma partida (risos): na zaga, lateral, meio-campo e ataque.

Mas o que mais me impressionava mesmo era o seu estado de espírito dentro de campo, ele invariavelmente sorria e dava gargalhadas quando estava jogando. Ele gostava muito de estar ali, era visível. Ele era alegre, jogava com um prazer descomunal. Isso eu levei de exemplo a minha vida toda. Ele estava inteiramente presente na situação de jogo, tipo o Luanzinho do Galo, guerreiro (risos). “Onde andará o Quim...?” Pra disputar as finais em Barra de São Francisco/ES, noroeste do estado - colado em Mantena/MG -, o Romário convidou três jogadores do Progresso pra virem pro nosso time: o
André, meio-campista, que, na época, ficou muito meu amigo - ele levava umas fitas cassetes do Fábio Júnior pra gente ouvir na concentração (risos) -; o Alex, goleiro monstro, que tinha uma grande explosão, dizem que jogou na base do Vasco; e o Chico, lateral-esquerdo, que chegou a se mudar pra Ibatiba, onde morou com a família do Ricardo, centroavante do time. 0 Chicão jogava muito e batia falta magistralmente, era fino, tinha um toque de bola requintado, teve passagens rápidas pelas bases do Cruzeiro e do América, onde foi campeão mineiro em 1993. Os três jogadores continuaram em nosso time até as finais de 1988.

Em 1987, nas finais em Barra de São Francisco, a gente ficaria por uns nove dias alojados numa escola pública se o time chegasse até a finalíssima, uns sete jogos, não me lembro bem. Ou seja, diversão na certa, pois, além do mais, eu me encontraria com meus amigos de bola de Lajinha (Guto, Rodrigo, Roger, Lander e Marquinho), que também chegaram à fase final jogando pelo timaço do Iúna, mas, por ironia do destino, logo foram desclassificados. 
Surpreendentemente, o nosso time foi jogando muito bem e foi passando de fase até chegar ao jogo final do campeonato contra a tradicionalíssima Desportiva Ferroviária. Perdemos de 2 a 1. Parecia mesmo impossível vencer. Eles saíram na frente e o Chico chegou a fazer o golaço de empate, de falta, de longe, mas eles eram bem melhores. Pra você ter uma ideia, o ponta-esquerda deles era o Sávio, aquele que jogou no Flamengo, no Real Madrid e na seleção. Na época, era o "Savinho da Desportiva". Ele desequilibrava.

Aldyr: Claro, claro, sei quem é...

Gustavo: O Sávio era espetacular. Eu nunca tinha visto um futebol daquele jeito, foi impactante. 0 time deles tinha outro tipo de postura física, eles tinham muito preparo, era gritante a diferença. Apesar disso, em 1988, foi feita uma seleção da Gazetinha pra disputar dois torneios no exterior, na Argentina e nos EUA, e foram convocados cinco jogadores do nosso time: o Guto, Alex, Chico, Quim e o Ricardo. Nas férias, eles foram treinar em Vitória e eu cheguei a ir, com o pai do Guto, a alguns treinamentos, onde pude ver o Sávio mais de perto. 0
Guto também achava o Sávio um cara fora de série, e passou a achá-lo mais ainda depois da viagem e dos jogos com ele.

Exatamente em 1988, em abril, nasceu o meu irmão mais novo, que também se chama Sávio. Eu sempre achei que, indiretamente, fui eu que escolhi o nome dele (risos), pois na época eu não parava de falar do Savinho com o meu pai. Sempre tive isso comigo, sempre me senti homenageado pela escolha de um nome que eu gostava, que eu vibrava ao pronunciar, mas nem sei se foi exatamente isso. Eu e o meu pai nunca falamos sobre o nome do meu irmão, mas eu soube há pouco tempo que ele ficou as duas primeiras semanas de vida sem nome (risos).

Aldyr: São as tais lembranças que vão ficando cada vez mais raras, essas coisas que cada vez menos gente é capaz de recordar, cada vez com menos precisão, com menos certezas... Isso está lá no conto "A falta de Tabaré" (risos)... ["E se transformam em dúvidas que os mais novos estimulam e tomam como exageros, como invencionices de quem vive no passado, dominado por uma nostalgia gostosa que se constrói de saudades alimentadas pela imaginação"]. 
Gustavo: Isso mesmo! Talvez tudo vire uma grande ficção. Nomes, letras, rastros de uma língua que não será compreendida num futuro distante...

Bom, caminhando pra finalizar o que já vem se tornando ficcional (risos)... Em 1988, em Cachoeiro de Itapemirim, agora, na categoria 14/15 anos, chegamos novamente às finais da Gazetinha e fomos derrotados apenas no último jogo: 1 a 0 pro Banestes, time da capital. Foi igualmente uma grande surpresa, ainda mais pelo fato de a grande maioria do nosso time ter 14 anos. Nessa temporada, eu continuei no banco de reservas, porque o Alex chegava uns dias antes de cada fase oficial da competição (e amistosos importantes) pra vestir a camisa número 1 . Eu era o titular durante os treinos semanais e amistosos regulares.

Devido aos grandes êxitos do nosso time, em 1988, fomos convidados a disputar a Copa A Gazetinha Internacional, em Cariacica/ES, Região Metropolitana da Grande Vitória. Jogamos no Engenheiro Araripe, estádio da Desportiva, onde ficamos hospedados por uma semana. Nós fomos desclassifica- dos na primeira fase, perdemos todos os jogos. Enfrentamos o Flamengo/RJ ( 4 a 0), o Banestes, se não me engano, e o Botafogo/RJ ( 1 a 0 ). Me lembro de jogar o segundo tempo contra o "Fogão", o Romário me pôs pra jogar.

O nosso time estava colocando o Ibatiba no mapa do futebol do estado. Viajávamos sempre com a bandeira do time e do município, que tinha sido fundado há pouco tempo, em 1981. ${ }^{11}$ A nossa delegação tinha até roupas especiais com distintivos da cidade pra circular pelos corredores da concentração. Eu até aprendi a cantar o hino de Ibatiba. Um de seus quartetos, inclusive, destaca o conflito da região: "Eis o município ibatibense / Força, união e distinção / Do estado

\footnotetext{
${ }^{11}$ Informações sobre a história da fundação do município de lbatiba: "Em 07 de novembro de 1981, o Distrito de lbatiba obteve sua emancipação política, desmembrando-se do Município de lúna. [...] Em 1975 o Distrito teve seu pedido de emancipação negado na Assembleia Legislativa, pois, segundo dados do IBGE na época, Ibatiba não possuía os 10 mil habitantes exigidos em lei para que o processo se realizasse. Somente em 1980, com um novo censo demográfico do IBGE, a população ibatibense atingiu a quantidade mínima exigida para abertura de um processo de emancipação". Site da Câmara Municipal de Ibatiba: https://goo.gl/AVDZAt.
} 
espírito santense / Membro desta área de tensão". ${ }^{12}$ Aprendi a cantar com o Canina, ponta-esquerda.

Já, em 1989, fui titular na primeira fase da Gazetinha. Estávamos no auge do vigor físico, bem preparados e "experientes". 0 time jogava junto há três anos, mas acabamos sendo desclassificados pelo time de Iúna, perdendo de 1 a 0 na casa deles. Dominamos a partida o tempo inteiro, o gol não saía de jeito nenhum. Bolas na trave, sufoco, pressão, correria, força, nada adiantou. Levamos um contra-ataque, só um contraataque, e tomamos o gol. Uma derrota daquelas inexplicáveis. Foi o meu pior momento no futebol (risos).

No final das contas, o time de Iúna acabou me levando pra disputar a segunda fase com o time deles, levou mais uns três de Ibatiba (Guto, Quim e Celso), mas novamente fomos desclassificados e tudo se acabou.

No entanto, ainda em 1989, no segundo semestre, também cheguei a disputar o Campeonato Municipal pelo juvenil do

\footnotetext{
${ }^{12}$ Conf.: "Hino do município de Ibatiba", letra e música de David Gomes
} Saraiva. Conf.: https://goo.gl/ntMda1.
União Futebol Clube, o time principal de Lajinha. A casa da minha mãe ficava, e fica até hoje, a um quarteirão do campo. Eu e o Guto disputamos esse campeonato juntos. Treinávamos à noite. Eu aprendia muito com ele. Sem dúvida alguma, o Guto foi o melhor jogador que vi jogar em Lajinha, o mais completo. Ele tinha força, raça, drible e inteligência, protegia muito bem a bola, além de chutar e cabecear com maestria.

Fui reserva durante esse campeonato inteiro, mas joguei a semifinal e a final, porque o Aladim, goleiro absoluto do time, tio do Guto, foi expulso do campeonato, nem me lembro bem o porquê. Eu tinha 15 anos, e o outro time, o Areado, só tinha uns caras grandões, adultos (risos). Eu estava morrendo de medo, tudo o que mais queria era ter uma desculpa pra não jogar, pensava até em forjar uma contusão, enfaixar o braço, sei lá... Perdemos feio pro Areado, 3 a 0, eu levei três gols.

Logo depois dessa partida, joguei as minhas luvas fora, arremessei pro outro lado do muro, pro lado do rio. Era um domingão com o sol cegando os olhos debaixo daquele gol. Eu estava meio puto, eu não queria mais saber daquilo. 
Mas, logo no início de 1990, o Atlético Mineiro mandou um olheiro ir a Lajinha pra observar um treino da meninada no campo do União. Ao final, ele escolheu dez jogadores, mas o clube mandou um telegrama pra apenas cinco: eu, Guto, Rodrigo, Caçapa e Quim. O telegrama, enviado pra cada um de nós, que também se perdeu no tempo, formalizava o convite pra fazer dois treinos no clube, na capital. Foi maravilhoso. Nós ficamos uma semana na capital, numa quitinete no Edifício Serramares, na Santa Rita Durão com Afonso Pena. Ir a Belo Horizonte e treinar na Vila Olímpica já era muito especial. Também assisti a alguns coletivos do time principal e vi de perto o Moacir, o Éder Lopes e o centroavante Gérson...

Naquela época, o Quim estava tentando voltar pro Galo, pois já tinha jogado um tempo no clube, só que ele quis voltar pra Santa Clara, porque estava sentindo saudades do sobrinho que tinha acabado de nascer. No final das contas, somente o Caçapa passou no teste. Ele era centroavante, era o mais novo dentre nós, mas ficou por pouco tempo no Galo. Ao Guto, me parece, foi solicitado que ficasse um pouco mais pra realizar outras avaliações, mas o pai dele preferiu que ele fosse pra Goiânia estudar, morar com um tio e tentar a sorte no Goiás, por onde treinou um tempo no juvenil.

Quanto a mim, já fui sabendo que as chances de passar eram muito pequenas. Eu tinha $1,74 \mathrm{~m}$ e tentava compensar a baixa estatura com uma boa colocação, o que já não era uma virtude quando se joga em alto nível. Minha mãe, pra me motivar, até dizia que poderíamos fazer um tratamento em Belo Horizonte pra crescer.

Pouco tempo depois, cheguei a fazer vestibular pra Educação Física na UFMG, pois eu realmente achava que só jogaria bola o resto da minha vida, mas acabei me formando mesmo em Psicologia e, mais tarde, em Letras pela PUC-Minas.

E, hoje, desenvolvendo pesquisas de pós-doutorado sobre as artes e o futebol, me reencontro com essa história toda.

Você acredita que até uns anos atrás eu tinha todas as tabelas dos nossos jogos pela Gazetinha guardadas num caderno? Eu tinha tudo anotado: escalação, quem marcou gols, local e data das partidas, substituições... Mas, um dia, o Guto me pediu esse caderno emprestado e tudo se perdeu (risos). Eu preci- 
saria procurar saber se existem registros disso em Vitória, ver com o Janc, sei lá...

Aldyr: Sua experiência com o futebol é muito rica...

Gustavo: Pois é... Eu, de fato, passei grande parte da infância jogando bola com os amigos. Uma experiência da amizade, do jogo, dos jogos da amizade, sabe? No campo, a gente jogava com 22 jogadores, e mobilizar isso não é fácil, mas não é mesmo! Tem que ter o empenho de cada um, além do apoio institucional, que nos estimulava muito. 0 time contava com o apoio da Prefeitura de Ibatiba, que fornecia excelentes materiais esportivos e pagava as passagens de quem morava fora pra treinar, além de todas as despesas durante a competição. Em dia de jogo amistoso, o motorista pegava a gente em casa, e o estímulo de almoçar em churrascaria quando a gente ganhava era incrível, era sensacional. Poxa, a gente voltava cantando, o Lobão era um dos hits na época.

Ao longo dos anos de 1987, 1988 e 1989, a gente sempre treinava no campo de Ibatiba aos sábados pela manhã e às terças e quintas ao final da tarde, até escurecer. A gente tinha técni- co, preparador de goleiros, juiz, roupeiro e até massagista (risos). Antes dos treinos, éramos orientados a dar dez voltas, correndo, em torno do campo. Era muito pesado. Hoje, acho que nem existe mais isso no âmbito da preparação física. Aos domingos de manhã, a gente jogava contra times da redondeza, tanto em casa como fora. Cada um dos times arcava com suas próprias despesas de viagem; por isso, retribuir a visita do adversário era questão de honra, o famoso "pagar o jogo". O Romário, o treinador, coordenava tudo. Ele era um cara muito dinâmico, comunicativo, sensível e inteligente. Era um grande educador, dava aulas de História na rede estadual de ensino. Durante os treinos, ele nos reunia direto pra falar sobre táticas e regras do futebol. Ele tinha um jeito bastante singular, um temperamento muito forte, explosivo, tipo o Bernardinho do vôlei. Ele sabia tirar o melhor de cada um do time, sabia o que queria da gente. Gritava muito à beira do gramado pra dar mais e mais gás pro time, não dava moleza. Com quem o Romário mais gritava era com o próprio filho dele, o Fabrício, que também jogava no time. Daí, a gente entendia/sentia, a parada toda. A exigência dele era uma coisa muito positiva. Vale 
dizer que o Fabrício jogava porque era muito bom, como o Bruninho na seleção do Bernardinho (risos). Ele atuava pelo meiocampo e, assim como eu, jogava como titular nos treinos e amistosos, ficando no banco de reservas durante as competições. Ele tinha um ano a menos do que quase todo o restante do time, era bem franzino.

O time de Ibatiba tinha muito a cara do Romário e a do Quim, que muitas vezes foi o nosso capitão. Os dois "conversavam" muito com o juiz (risos). o Romário gritava muito com o juiz, catimbava o jogo, ria, ria com ironia, corria, pulava, esbravejava. Ele sabia tudo sobre as regras do futebol, pois também apitava jogos dos campeonatos na redondeza. Veja, o cara era até juiz (risos).

Assistir ao Romário como treinador em ação no/do banco de reservas era uma atração à parte. Hoje, percebo o caráter pedagógico de todas as suas atitudes. 0 lance da ética, do jogo, da vida... A presença dele em campo com aquela energia toda, tinha paixão na coisa, sabe, muita entrega. Ele tinha muita noção do ritmo das partidas, do clima do jogo, e traduzia pra gente em palavras, gritos e muitos gestos. Ele tinha uma voz potente, com muitos recursos, embora já o tenha visto rouco não poucas vezes, e com certeza conseguia imprimir o seu "jeitão" em nosso time.

Fora de campo, nos momentos de convivência, o Romário era muito afetuoso. Aos sábados, depois dos treinos, a gente almoçava direto na casa dele, sua mulher sempre preparava a comida, eles eram muito generosos. A gente falava sobre futebol o tempo todo, ele torcia pro Botafogo.

Foi uma pena a gente não ter convivido na vida adulta, ele foi embora muito cedo. Eu gostava muito dele. Sem dúvida alguma, foi o meu melhor professor daquela época, um grande líder, um grande educador, eu ficava muito atento às suas instruções. Na verdade, minha educação se deu mesmo, ou em grande parte, fora da escola.

Em 1990, eu já não podia mais jogar por causa da idade avançada, segundo as categorias da Gazetinha. Então, o Romário me chamou pra ir como roupeiro do time de Ibatiba numa edição especial da competição - Copa A Gazetinha Nacio- 
nal - em Ibiraçu/ES, Litoral Norte do estado. De Lajinha, também foram o Caçapa, o Rodrigo, o Fabrício, o Fabiano, muito bom goleiro, e o Léo, sensacional lateral-direito, raçudo e inteligente.

Eu tinha a função, dentre outras, de distribuir as camisas no vestiário, onde seguíamos com rigor o ritual de sempre, não necessariamente nesta ordem: juntar-se cerca de duas horas antes da partida, lanchar, conversar sobre o contexto do jogo, o Romário sempre sabia muitas informações sobre o time adversário, distribuição da camisa e escalação da equipe, tomar uma rodada de guaraná em pó pra ficar mais ligado (risos), aquecer, unir o grupo em roda, ouvir o discurso motivacional de um ou dois jogadores, rezar - Pai Nosso e Ave Maria - e, por fim, soltar "gritos de guerra". o Romário também sempre batia um papo individual com algum jogador para melhores esclarecimentos táticos.

Enfim, me deixei tomar por essas lembranças e já devo estar delirando (risos). Eu só queria te contar essas histórias pessoais, porque seu livro foi um canal pra despertá-las. Afinal, seus contos têm muito de suas memórias futebolísticas de infância nos anos 1950 em Jaguarão, suas experiências fronteiriças... Nesse sentido, seu livro me sensibilizou muito. Poxa, é indescritível mesmo...!

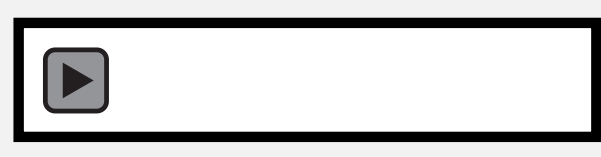

\section{Áudio 1: trecho da entrevista. ${ }^{13}$}

Link: http://bit.ly/FuLiA-UFMG-futebol-local.

Aldyr: Tens uma experiência mais rica do que eu com o futebol, né. Eu fui preparado na escola pra praticar esportes, e entre outros o futebol. Não dei certo em nenhum, inclusive no futebol. Mas eu aprendi, por exemplo, na escola, atividades básicas do esporte. Nós tínhamos que saber jogar com os dois pés, passar com os dois pés, chutar com os dois pés. Fomos treinados pra isso. Claro que eu jogo com os dois pés se eu quiser. Jogo, não, jogava (risos).

\footnotetext{
${ }^{13}$ Importante: para ouvir o áudio é necessário baixar este PDF para o computador, recomendamos o uso do Adobe Reader ou Foxit.
} 
Gustavo: [Nas peladas em Lajinha], eu me forcei muito a jogar com a esquerda, porque meu ídolo era o Éder. Então, eu ficava na ponta-esquerda pra entrar com a direita metendo gol...

Aldyr: Aquele canhão no pé, né.

Gustavo: Isso! Eu ficava tentando cruzar e de vez em quando dava...

Aldyr: É... Mas nunca foi um sacrifício, sempre foi uma satisfação muito grande jogar bola. E jogaram no nosso time dois jogadores que foram campeões gaúchos pelo Renner. 0 nosso técnico era o técnico do Renner. Nosso médico era do Renner. E saiu lá de Jaguarão, não porque fossem jaguarenses, mas porque o IPA (Instituto de Porto Alegre), o colégio onde estudei, que era uma maravilha, adotava a metodologia e a filosofia do John Dewey, filósofo norte-americano, que era o filósofo da liberdade, da responsabilidade.

A escola era uma revolução. Nenhuma escola no Brasil tinha adotado ainda esse modelo, e ele preparou professores em Dallas. Os caras estagiaram durante um ano e meio lá, na SMU. E quando ia instalar, no Rio Grande do Sul, a escola, com esses professores, a maioria deles de Porto Alegre, o Conselho Estadual de Educação, com padres e freiras de tradicionais colégios católicos da capital, não permitiu - "aqui, não, isso é troço de protestante!". Então, o Conselho Estadual de Educação negou a aprovação dessa escola, com essa metodologia e com essa filosofia. 0 governador do estado, era época da ditadura do Getúlio, era o interventor federal (risos) do ensino aqui, Cordeiro de Farias, um cara de Jaguarão. Esse cara conseguiu, com facilidade, que o IPA fizesse o departamento em Jaguarão. E aí passou no Conselho Estadual de Educação a possibilidade do IPA ter um departamento, em Jaguarão, que funcionasse com o padrão Dewey. E eu tive a felicidade de ser aluno do segundo ano até a quarta série dessa escola, o tempo que ela durou em Jaguarão. Eu também entrei no segundo ano só com um teste... Minha avó já tinha me alfabetizado.

Então eu tive a felicidade de participar dessa escola que, depois, também surgiu em Minas Gerais, no mesmo padrão, numa cidade famosa... Não tô me lembrando o nome da cidade agora. Mas o IPA já tinha sido fundado, já estava andando. Eu 
já estava pela $5^{\underline{a}}$ ou $6^{\underline{a}}$ série, e a gente passava o dia inteiro no colégio, mesmo não dormindo no colégio.

A gente tinha um horário espantoso. As aulas eram das sete da manhã ao meio-dia; depois, da uma e meia até quatro horas. Tínhamos horário de estudo, a gente podia estudar o que quisesse. Podíamos fazer um estudo dirigido, ou seja, se o meu problema fosse de Português, fosse de Matemática, eu tinha que procurar um professor de Português ou de Matemática que não fosse o meu professor, pro cara me orientar pra fazer os temas de casa.

A partir das quatro horas da tarde: esporte. A gente, depois dos 11 anos - limite pra começar o Ginásio naquela época -, passava a cada seis meses por uma experiência inicial envolvendo alguns esportes. Claro que futebol, basquete, vôlei não havia futebol de salão -, ginástica olímpica, remo e natação. Quando o IPA não tinha o equipamento, como o caso do remo, que eu pratiquei, fazia um contrato com o clube náutico da cidade; na época, tinha o Clube Náutico Minuano. Eu não tinha físico pra remar (risos), eu era o patrão. Quer dizer, passei até por isso, aos domingos de manhã (risos).

A gente tinha paixão pela escola. 0 médico da escola, o doutor Deli Monteiro, o técnico e alguns ajudantes, todos eram oriundos do futebol de Porto Alegre. 0 nosso zagueiro era o Orlando, Orlando Romagna, e o lateral-esquerdo, depois ponteiro do Renner, Paulistinha, não lembro o nome. Esses dois caras eram do time permanente do colégio. E quando foram pra Porto Alegre, levados pelo médico e próprio técnico, Silvino Rodrigues, eles foram titulares e campeões gaúchos pelo Renner, em 1956. Então, tem uma história fantástica. E uma ligação muito grande com o futebol.

Gustavo: E o campeonato municipal de futebol em Jaguarão?

Aldyr: Em Jaguarão, os times jogavam o campeonato jaguarense, e os de Río Branco jogavam o campeonato de lá. Tinham quatro times em cada um, no mínimo. Os jogos aconteciam a cada quinze ou vinte e um dias. Por exemplo, quando a gente tinha cinco times em Jaguarão, era evidente que a rodada não fechava. O que sobrava ia jogar em Río Branco. 
Durante um campeonato inteiro, não lembro com certeza o ano, mas foi entre 1942 e 1949. Havia o Cruzeiro, o Jaguarão, depois o Harmonia, o Imperial, o Mauá. Então, com quatro times, as rodadas eram cheias, mas quando entrava outro, como o Independente ou o Sete de Setembro, que eram times que não duravam muito tempo, times de várzea que, no verão, funcionavam bem, depois no ano inteiro não conseguiam se manter, porque os melhores jogadores iam pro Cruzeiro ou pro Harmonia... E em Río Branco acontecia coisa parecida. Tinha o time do Río Branco, o Ferroviário, que era um time muito importante mantido pela Asociación Ferrocarril Inter Uruguay. E mais: o rádio fazia com que a gente acompanhasse o futebol do Uruguai e o argentino, e os jornais também. Tinha também o Artigas - estão destruindo o campo do Artigas pra criar mais uma Duty Free por ali. Só quem conheceu sabe que ali era um campo de futebol, na entrada, ou saída, de Río Branco, em direção a Montevidéu.

Eu nasci ali perto, a duzentos metros do rio. Tenho repetido sempre que é uma parca, mínima, distância de duzentos me- tros do Uruguai, na altura da rua Marechal Deodoro, uma casa a uma quadra e meia adiante.

Gustavo: A duzentos metros do rio?

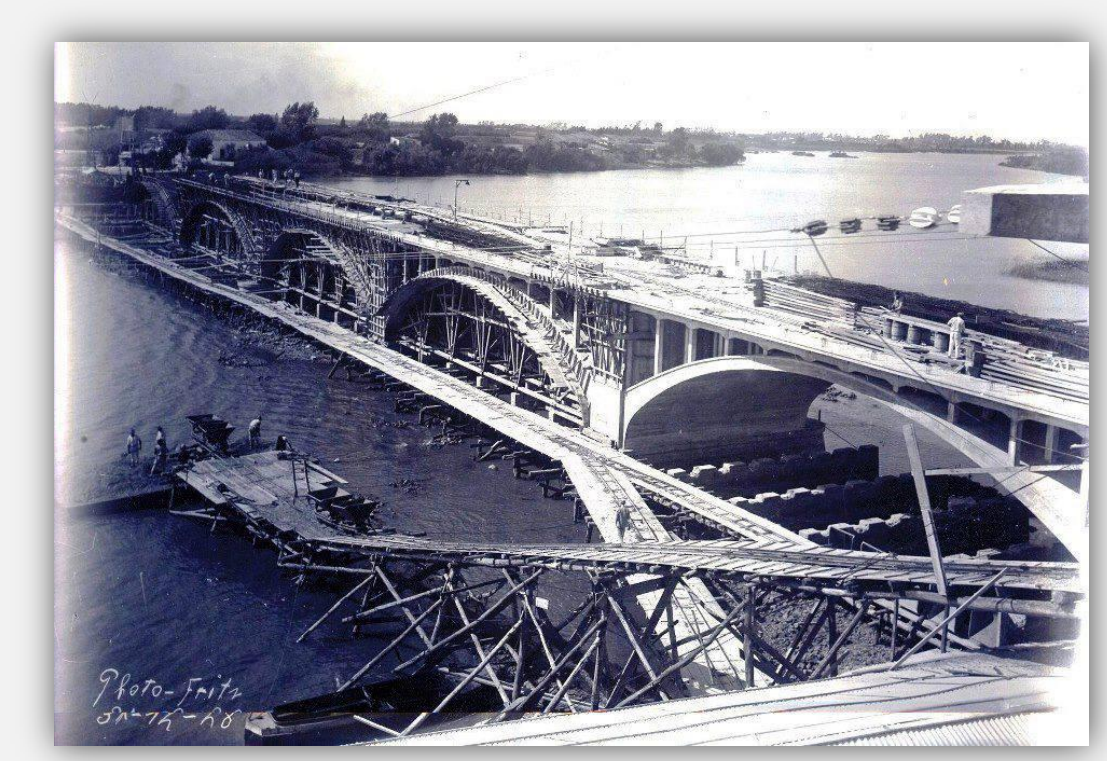

Ponte Internacional Mauá, inaugurada em 1930, une as cidades de Jaguarão (Brasil) e Río Branco (Uruguai). ${ }^{14}$

Aldyr: Menos. Eu conto a metade do rio pra chegar no Uruguai (risos). E eu nasci na casa da minha avó, num parto caseiro, e

\footnotetext{
${ }^{14}$ Fonte da imagem: Família Prati (Fotos Antigas RS): prati.com.br.
} 
fiquei até alguns meses ainda nessa casa. E depois, então, o meu pai tinha montado um hotel em Jaguarão, chamado Hotel Natal, curiosamente natal de nascimento, onde nasceria logo depois minha irmã, segunda da família, dos meus irmãos. Esse hotel era requintado, meu pai tinha mania de grandeza e estava ganhando muito dinheiro com a construção da Ponte. Ele trazia nos barcos dele e dos irmãos todo o material pra construir a Ponte e a estrada de ferro, e isso custou pra eles, os Schlees, uma dificuldade muito grande posterior.

Eles achavam que estavam construindo a sua riqueza, mas estavam se desfazendo da sua riqueza pra construir a sua miséria, porque no momento em que a Ponte estava pronta e os trilhos correram por cima dela até Montevidéu, e até São Paulo, não haveria mais vez pra navegação fluvial e lacustre, que eles também exerciam. Daí eles foram tentando outras atividades, e a primeira que meu pai começou a tentar, em 1939, foi o hotel, que ele já estava projetando desde o meu nascimento. Ele contratou jardinistas franceses de Montevidéu (risos) pra fazer um jardim no meio...

\section{Gustavo: E esse hotel ainda tá lá?}

Aldyr: Ainda tá lá, mas hoje tá transformado em Círculo Operário Pelotense. Mas, e por aí foi, né... 0 meu pai teve uma porção de atividades paralelas, perdeu muito, teve alambique de cachaça, teve fábrica de sabão, fábrica de corda, fábrica de calafate pra navio, porque ele nunca deixou de estar vinculado à indústria naval. Mas ele vendeu os navios e depois vendeu tudo e veio pra Pelotas pra criar um grande centro de distribuição de produtos coloniais, importação e exportação com os barcos que ainda restavam deles.

Gustavo: E você veio junto?

Aldyr: Não. Aí aconteceu um desastre, uma grande enchente que levou tudo por água abaixo, e foi aí que eu tive que ficar morando com a minha avó.

Meus irmãos gêmeos nasceram em 1941, e, em 1942, eu fiz um teste pra começar no $2^{\circ}$ ano primário, no IPA. Passei nesse teste, e a minha avó passou a pagar os meus estudos. Meu pai foi trabalhar em Santa Cruz do Sul como viajante de seguros de cinco companhias de seguros que havia aqui no Rio Grande 
do Sul, Sul América, essas companhias comuns, e foram morar em Santa Cruz do Sul, que era mais no centro do estado. E o meu pai falava alemão e pomerano. Então, ele tinha contato com essas pessoas e não era nazista, isso era exigência das companhias (risos), o que foi muito bom também pra minha formação... Escapei (risos).

Gustavo: Essa sua experiência foi mesmo ali na fronteira?

Aldyr: Bom, a grande perplexidade, que acompanhou a minha infância e até a adolescência foi a do rio, foi aquele rio. Aquele rio, ali, separando de maneira que não se podia de nenhuma forma justificar duas culturas. Que na verdade eram uma só, mas, aparentemente, duas línguas, duas maneiras de agir, duas maneiras de pensar, tudo. Duas formas diferentes de vestir, chegava a esse ponto. 0 apego do lado de cá por determinados costumes e tradições, e o desapego do lado de lá. Isso tudo era encantador e ao mesmo tempo desafiador e fez com que eu fosse um sujeito, não vou dizer contestador desde o início, mas me levou a ser um contestador, e também me encheu de sonhos, ilusões, me permitiu ver a realidade com outros olhos e me transformou num escritor.

Primeiro, um pretenso desenhista. Eu fui desenhista profissional durante um bom tempo, e, nessa condição, chegou um momento que o meu meio de expressão já não era mais o traço, era a palavra. Aí as coisas mudam, porque as palavras têm sempre algum significado.

Eu gostaria de escrever um livro em que ele pudesse desafiar a palavra tirando o seu significado e a apresentando só com uma coisa ilustrativa, capaz de encantar como uma obra de arte... Mas não há como fugir do sentido da palavra. Seria uma loucura isso também, né (risos). Eu acho que com isso eu respondo a sua pergunta.

Gustavo: Sim, sim, claro.

Aldyr: Mas um dos elementos que fez com que eu vencesse essa perplexidade, digamos assim, e me sentisse muito mais do lado de lá do que do lado de cá, que me levaria a atitudes de uruguaio e não de brasileiro, é pelo fato de que as comunicações com centros maiores do Brasil eram muito mais difí- 
ceis do que com as comunicações não só com o Uruguai inteiro, mas até com Buenos Aires.

Houve um momento em que uma pessoa teve grande importância na minha formação, e na minha vida, o padrinho da minha irmã, Capitão dos Santos Roxo. Ele passou a assinar pra mim os jornais de Montevidéu, um jornal de Buenos Aires e as revistas semanais de futebol do Uruguai e da Argentina. El Gráfico era espantoso! Era realmente a maior revista futebolística à qual a gente podia ter acesso.

Gustavo: Você tinha quantos anos?

Aldyr: Ah, eu tinha 10 ou 11 anos. Entre o início das minhas aulas no IPA e uns dois anos depois, em 1944 ou 1945. Nesse momento, a Ponte passou a ser outra coisa pra mim. A Ponte, que tinha sido construída de certa maneira pelos meus tios e pais, porque sem o material que eles levaram não haveria ponte. Eu me encantava por isso... A Ponte passou a ser um traço, não a prova de separação entre os países, mas um traço de união, como era mesmo, entre os dois. E a proximidade do Uruguai se torna local, até da Argentina através dos seus veí- culos de comunicação locais, porque antes a gente levava três dias pra receber a edição de domingo do Correio do Povo. Chegava na terça, via férrea, era uma volta enorme. Agora, a gente tinha ao meio-dia os jornais de Montevidéu e de Buenos Aires e, ainda, nas segundas-feiras, El Gráfico, de Buenos Aires, e o Mundo Deportivo, de Montevidéu.

Aí o futebol chega e começa a substituir aqueles bonecos, aqueles recortes dos álbuns de figurinhas que antecederam a minha própria alfabetização. E que eu adorava e guardava como relíquias. Mas os jogadores eram aqueles que ainda continuavam sendo citados pela imprensa argentina e uruguaia, porque havia jogadores, inclusive brasileiros, inesquecíveis no futebol de Buenos Aires ou da Argentina. 0 futebol argentino naquele tempo era só o de Buenos Aires, mas o inesquecível Divino Mestre, Domingos da Guia, estava lá nos álbuns, ele estava lá sendo ouvido na Argentina. E os grandes jogadores todos, que no Brasil não são tão reconhecidos, e os novos craques que agora não encantavam. 
Ainda antes desses veículos de comunicação, pelo rádio, o tricampeonato do Flamengo, com aquele time que continua na nossa memória, formado em fila indiana... Aquela imagem do Flamengo em fila indiana é uma imagem extraordinária: Jurandir, Domingos e Quirino, Biguá, Bria e Jaime, Adilson, Zizinho, Pirilo, Perácio e Vevé. ${ }^{15}$ Poxa, nunca mais vou me esquecer, e também tinham outros.

O mundo saía do seu eixo de certa maneira, o mundo futebolístico, porque ele estava centrado lá no Uruguai e lá na Argentina. Mas comecei também a ter acesso através da revista Esporte Ilustrado, semanário brasileiro do Rio de Janeiro, do Levy Kleiman. Passei a ter acesso a duas coisas importantes: o noticiário sobre o campeonato carioca com todos os jogos, todos os times, fotografias dos times de cada semana - tradicional foto aquela, dos times, Botafogo e Bonsucesso; e o futebol de Minas Gerais, alguns craques que passaram a jogar no Flamengo ou no Vasco e no Rio de Janeiro, por exemplo, Lelo, Nívio [Gabrich]...

$\overline{15}$ Os jogadores da foto eram: Jurandir, Quirino, Nilton, Valido, Jaime, Bria, Pirilo, Zizinho, Tião, Biguá e Vevé.
Gustavo: Zé do Monte...

Aldyr: Zé do Monte, o Gerson, que fez a zaga do Botafogo, Kafunga... Esses jogadores todos passaram a fazer parte do meu universo literário, digamos (risos), porque aí estava tudo projetado junto num campo de sonhos, de alegria, de beleza, que tinha que ser explorado literariamente. Com esses, eu não cheguei até o livro, pode ver. No livro, só tem aquele álbum que eu guardei, que é verdadeiro (risos), que eu guardei com tanto carinho... Em 1958, eu me lembro de comprarmos o álbum, eu e meus irmãos, eu financiei (risos).

Gustavo: Você já estava com 23 pra 24 anos...

Aldyr: Sim... Eu financiei a compra de um conjunto completo, tinha um nome que se dava a esse conjunto completo de camisetas de futebol, do Corinthians. E guardei uma camisa do Pelé e o meu álbum de figurinhas, esse que está citado no livro. Guardamos o álbum, mas acabou sumindo no meio de uns guardados, aí se foi meu álbum, senão estaria aqui à disposição pra ver... Mas onde nós estávamos mesmo? Nós estáva- 
mos falando sobre futebol, Jaguarão, a fronteira... Ah, o sentimento de fronteira, essa questão do fronteiriço.

Gustavo: Isso. O fato de Jaguarão e Río Branco se parecerem mais entre si, do que com Porto Alegre e Montevidéu, respectivamente, é criado um modo singular de pertencimento naquelas cidades. Inclusive, esse é o mote do artigo sobre o seu conto "Empate", que publicamos na revista Aletria. Portanto, eu queria saber, e você já falou, sobre a sua própria experiência fronteiriça, que já aparece na narrativa de abertura do livro Contos de futebol, "Aquela tarde impossível", que é um conto muito singelo e belíssimo, tratando dessa questão de maneira muito particular e intensa. Que experiência incrível é a daquele menino no cinema em Río Branco na mesma hora da final da Copa do Mundo de 1950 entre Brasil e Uruguai, hein?! E ao mesmo tempo é e não é a sua própria história (risos)... Afinal, o que é narrado é uma experiência coletiva, própria daquela região: ser brasileiro e igualmente ser uruguaio. E é muito bom saber que, de modo geral, o pessoal de Jaguarão já está lendo os seus livros. Poxa, afinal, eles narram as histórias daquele povo, né?
Aldyr: Agora ficou uma leitura acadêmica, mas com boa repercussão, muito boa repercussão. A curiosidade superou tudo.

Gustavo: Que bom que você tá vivo pra ver isso... Podemos fazer uma pausa?

pro Luiz Heron da Silva, sensível aos encontros (e desencontros) da vida;

pro Elcio Cornelsen, por apontar o caminho do futebol com as letras (e a memória);

pro Romário Nóia (1957-2012), em especial. 


\section{ANEXo}

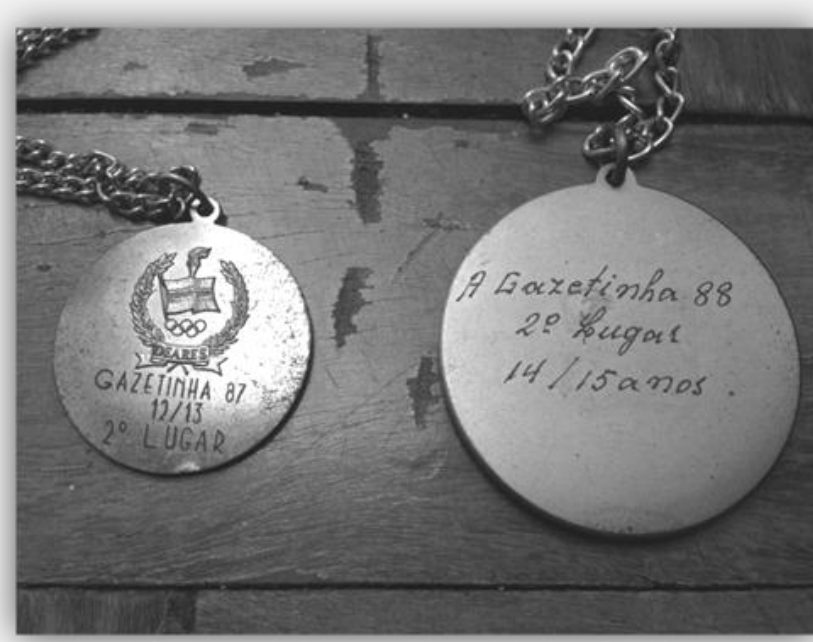

Medalhas do vice-campeonato da Copa A Gazetinha de Futebol Infantojuvenil conquistadas pelo time de Ibatiba/ES, em 1987 e 1988.

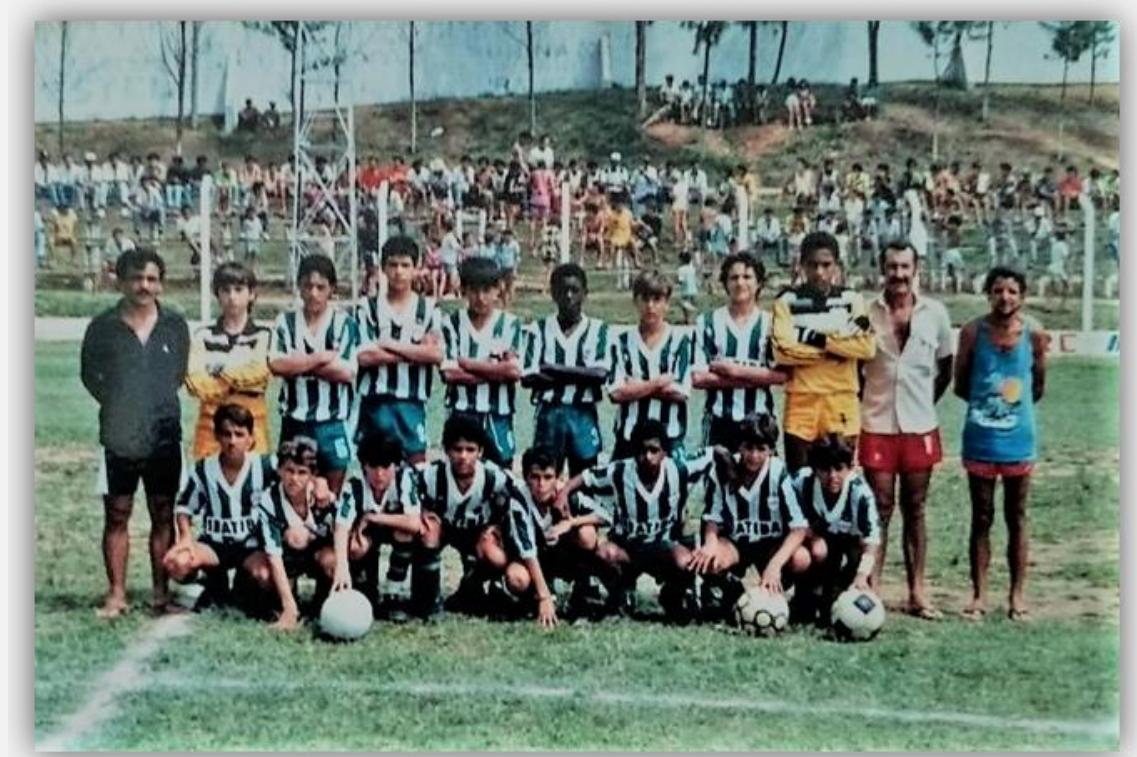

Time de Ibatiba em 1988. Em pé: Romário, Gustavo, Quim, Ricardo, Celso, Chico, André, Guto, Alex, Zé e Rossini. Agachados:

Carlinhos, Dodó, Zezinho, Maradona, Fisuca, Neguinho, (?) e Fabrício. 